\title{
Searching for Solid Ground in Polish- American Relations in the Second Year of the Trump Administration
}

\author{
Bohdan Szklarski \\ University of Warsaw \\ American Studies Center \\ e-mail: bohdan.szklarski@uw.edu.pl
}

\author{
Piotr llowski \\ Polish Academy of Sciences \\ Institute of Political Studies \\ e-mail: piotr.ilowski@wp.pl
}

\begin{abstract}
Since the beginning of the Trump Administration, analysts of American foreign policy have observed several changes in the style substance and style of Washington's international behavior with regard to both foes and friends. President Trump in his rhetoric (including social media communication) and style represent a disturbing discontinuity, especially for allies that undermines the stability of American international commitments. American allies are forced to develop new strategies for managing this new risk in relations with Washington. This paper examines the tactics employed by the government in Warsaw in that regard.
\end{abstract}

Keywords: policy style, uncertainty, risk management, continuity, bilateralism, special relations, alliance, Donald Trump. 


\section{Introduction: the stage is set for new understanding of allied relations}

In the first almost two years of Donald Trump administration's relations with Warsaw, we could observe a number of tendencies, which can be epitomized as a departure from structural asymmetry (based on long term commitments, shared interests and axiological proximity) in favor of transactional asymmetry (based on calculation of costs and benefits spruced with symbolic reiterations of traditional bonds). Trends that have appeared or have been strengthened since January 20, 2017 on the American side are: ${ }^{\star}$ the emergence of pragmatism, ${ }^{\star}$ searching for extemporaneous balance of benefits, ${ }^{\star}$ disclosure of links between foreign and domestic policy, ${ }^{\star}$ intention to view the relations in the broader context of relations with Russia and with the EU; on the Polish side we witness: ${ }^{*}$ increased attention seeking, ${ }^{\star}$ emphasizing long term rules and institutional ties, ${ }^{\star}$ seeking recognition, ${ }^{\star}$ searching for bilateral usefulness to the US outside of multilateral relations. What is clearly visible on the Polish side is the fear of devaluation of relationship with Poland which reflects the increased level of risks in allied relations that the Trump administration has brought to all its partnerships. This article describes how a junior partner in an alliance tries to comprehend and deal with the new uncertainties in search of ensured security.

This picture has captured attention of serious analysts as well as a multitude of casual observers of international politics: President Donald Trump comfortably sitting behind a huge desk in the Oval office, signing some document and next to him is Polish President Andrzej Duda, standing and leaning over some documents which he is also signing on the corner of President Trump's desk. For seasoned followers of politics hardly ever does one come across an image so well representing asymmetry in relations between two partners. Saturday Night Live would not have come up with a better depiction of a master king treating his partner as a vassal. When one adds to the picture the actual offer made by President Duda in that meeting to actually pay \$2.0 billion for American security guarantees to Poland in the form of a permanent military base on the Polish soil, the irony turns to serious concern. It raises a legitimate question as to the degree of risks permeating the Polish-American relations.

The accumulation of new emotions and viewpoints makes the period between 2017 and 2018 a time of intensive asymmetry of relationship in the context of increased risk and poorly concealed anxiety regarding the continuity and quality of the bilateral relations. We can talk about changing the formula of "partnership utility", in perceiving the benefits and costs associated with maintaining alliance at the previous level. The strategic and axiological model of seeing the world propagated by its predecessors is being replaced by transactional, bilateral and business-like cost balancing way of evaluating relations with allies. A change 
in the philosophy of international relations in Washington and the definition of US presence and leadership in the world means that Poland's role and its policy are assessed there to a much lesser extent through the prism of a long term partner, or even a "Trojan horse" of America in the European Union and other international organizations (Zając, 53).

Questioning the value of bilateral relations means that Trump allies, to whom Poland would like to count, have to prove their usefulness and their (potential) value to Washington. They had to do this more often than in the previous US administrations which seemed to understand that in allied relations, asymmetry is a natural state. By making a much larger contribution to the relationship, the United States as a stronger partner, only expects readiness for verbal support at a declarative level from a smaller partner. That is why, the new philosophy of Donald Trump's politics has cast doubt on how much such support will be considered sufficient. He introduced uncertainty to allied relations, by opening a discussion about the nature of mutual obligations and benefits. This is a new quality that has replaced previous, routines and automatism, which were the foundation of a friendly asymmetry during their predecessors' administrations. Current American allies do not know for sure how much to invest and what will be considered as "sufficient involvement". In other words, they are less sure what is an adequate manifestation of loyalty to the United States these days. Therefore, they are looking for a new ways of managing uncertainty or even risk in the bilateral relations with Washington.

Paradoxically, many US allies such as Poland wanted to tighten their relations with the United States as a guarantee of security. Poland pursued such dual course: collective security guarantees under NATO and bilateral additional assurances by way of "special relations" with Washington (similar to London), which was supposed to not only increase prestige internationally and within EU structures, but also give Warsaw an additional reassurance (Kiwerska, 68). However, it was believed that Polish-American relations, before 2017, are stable and the contribution to the alliance does not affect the level of the US commitment. It was believed that America understands that in the relations of non-confrontational asymmetry it bears a greater material (military) burden than a smaller partner whose contribution to the relationship often consists of verbal support and declarations of willingness to promote the "shared interests". This imbalance legitimized American leading role and enabled it to take for granted the support of a permanent group of allies "through thick and thin".

Those allies believed that the United States could test this support only occasionally (by allies: participation in joint international missions, voting in international organizations, sharing intelligence, import of American goods and technology, or procurement of American weapons). It was because of the fact that Washington was to be guided not only by the economic and political benefits but also by the symbolic and axiological dimension of partnership. 
In the last two years, messages coming from the White House cast doubt on this axiological approach to balancing the relationship. From January 2017, the Trump administration constantly reminded that it expects more than a declarative contribution to alliances. Washington is trying to change its ongoing policy of multilateralism and cooperation within international organizations. It prefers bilateral relations (which countries such as Poland desire) where, it can impose more tangible balanced contribution. In other words, Trump expects his allies to show more of their usability and loyalty to the US. In this sense Polish and American approaches are compatible.

However, if the allies are not sufficiently involved in mutual relations, they are threatened with repercussions. This is a new quality for those countries that have not previously heard, or refused to hear, about the possible reassessment of US commitments (Beaumont). One of the examples of a possible change in the relationship was the controversial law of Poland's Institute of National Remembrance (IPN). In January 2018, the State Department openly announced its dissatisfaction with the Polish law which, if implemented, could have introduced nationalistic filters and censorship on the freedom of research on Holocaust. Washington said in not too subtle words, that in such case the United States was ready to reconsider the nature of mutual relations (Świerczyński). Such an open declaration of dissatisfaction and the threat of devaluation of the Polish situation shocked the Polish authorities and caused them to withdraw from this law by changing most controversial parts of the act in less than six months. This situation showed that good relations with the United States are not unconditional and can change rapidly which undermines the current assumptions of Polish diplomacy and national security. This open conflict forces the analysis of the compensation tactics that can be implemented to minimize the risk in asymmetrical alliance relations between Poland and the US, which is the purpose of this article.

For Poland, located in the center of Europe with historically troubled relations with its neighbors (Russia and Prussia/Germany), the search for support for its sovereignty through the establishment of lasting allied relations with a stronger protector is not an unknown experience. After the Second World War, Poland found itself in the so-called "Eastern bloc," whose protector was not chosen but imposed by force. The collapse of the Soviet Union in 1991 did not eliminate the historically shaped concern about understanding international policy in Central and Eastern Europe as a fight for the sphere of influence. That is why, the Polish authorities tried to adapt to this situation by finding themselves in the structures of two institutions: the European Union and NATO. These "new protectors" were to be the foundation for the security of Poland and other Central European countries (in the economic dimension - the EU, and the political and military - NATO). It is worth noting that in Poland NATO is seen as an intermediary institution in providing US security guarantees. For Poland the United States were seen as a new protector that was 
chosen, not imposed. Seeking extraordinary and unilateral assurances of "security and friendship" directly from the US became an additional raison d'etat for all Polish governments, irrespective of their ideological orientation.

American security assurance for Poland was never seriously challenged in public discourse either. Only certain minor left-wing groups treated this situation at the beginning of transformation as a dictum resulting from the no-alternative of that "choice" of the path to development even though together with the guarantees of security came the introduction of liberal capitalism in the form of a "shock therapy" (Szymański, 133). On the other hand, right-wing nationalistic parties despite their attachment to "Polish sovereignty" did not question the American patronage (and liberal capitalism which came in a package) mainly due to possible danger coming from Russia. Being caught up geopolitically between Germany and Russia throughout ages Poland used to consider security as a formidable interest, an absolute priority. Therefore, despite some minor criticisms, overwhelming elite consensus as to the general predicaments of the Polish geopolitical situation during the last thirty years after Poland regained its sovereignty, results in limited public discussions on the foreign policy strategies among key domestic actors (BieńczykMissala, 103). The diversity in academic analyses seems to be only somewhat greater (Kuźniar; Zięba). Today in the era of heightened populism, the same concerns mitigate Polish Euroskeptics.

It seems that acceptance for replacing the Russian for American and the European Union "protectorate" is unequivocal. Polls strongly confirm these perceptions both at the level of elites and average citizens (Stone). This cultural and historical context of foreign policy is an important factor shaping Polish reactions to what flows across the Atlantic from January 20, 2017. President Trump, like his predecessors, must be aware of this predicament for when he addresses Poles he skillfully continues to touch the right buttons of pride and sense of historical mission and exceptionalism.

Poland has "invested" in the United States as the main partner in the international arena, especially in the sphere of security. The result of this decision are attempts to bring its own interests closer to the US. It should be noted that the situation when such a strategic foreign policy decision is made is not anything extraordinary for countries entering a new path of development. The situation of Poland can be compared with the one in which Mexico found itself after the First World War when it entered the path of democracy. The strategic choice was the decision how the weaker state should define its relations with a stronger neighbor. One way was to have similar policy like other Latin American countries and follow an antiAmerican and nationalist course. Another option was to accept asymmetrical relations with the US and seek a lasting economic and political arrangement. It was this latter way that the authorities in Mexico chose and accepted "peripheral utilitarianism" (Łaciński, 133-134). The final stage of entering this agreement for Mexico was 
the signing of North American Free Trade Agreement (NAFTA) in 1994. As a result of this an informal and lasting agreement was reached between the elites of both countries. This "ideological agreement" is shared by all entities on both sides of the border, or at least it was before Donald Trump was in the Oval Office.

However, the main difference between Poland and Mexico lies in the fact that the latter is in the traditional American sphere of influence, and Poland is located many thousands of kilometers from the US. What is more, Mexico does not have any traditional rival or enemy at its borders... other than the US. NATO was perceived by such states as Poland as an extension of the American border in close proximity to Central Europe. That was why the authorities in Warsaw have made efforts to enter this zone since the very beginning of the transformation. Currently, the Polish raison d'état is to cultivate in Washington the conviction that Central Europe is the space where America has vital interests. The decision to export LNG appeared quite conveniently almost simultaneously with the arrival of a transactionist and deal oriented president in the White House.

Thirty years ago, it was easier to convince the United States to become more involved in Central Europe because it was in the line with Cold War logic. Washington treated it as a "spoil" taken from the enemy (Moscow) (Zachara, 1). Today, almost three decades after the collapse of the Soviet Union, it is more difficult to justify permanent presence of the Americans in Poland and in the region. The key for a smaller partner is to create and provide the Americans with narrative that could include the right combination of axiological and material incentives. What's more, this "justification" must resonate in Washington so that they do not begin to question the legitimacy of maintaining its permanent military and political presence in the region. At the moment Poland pursues this effort along two lines: by offering itself as a trade partner for the LNG long term export deal and by signing multi-million military contracts for anti-aircraft Patriot missile systems. Both tactics provide president Trump with what he likes most: a tangible investment into alliance.

The quality and intensity of relations between America and Central Europe depend on two considerations: one is the state of affairs between Washington and Moscow, and the other, quite unexpectedly, the state of relations with the EU. That latter dimension for decades used to be noncontroversial. NATO and EU relations could be treated jointly as both dimensions define context for relations with Europe that for decades have been a foundation of trans-Atlantic alliance. Today's "differences of opinion" with regard to trade issues, NATO article 5 interpretations, and lower than 2\% GDP levels of security expenditures have devalued trans-Atlanticism from a "taken from granted" to "debatable" status.

With regard to the US-Russia relations the Polish calculations are steady. If the relations become "warmer" and Russia is seen as a potential partner responsible for the fate of the world, then the US perception of threats coming from Moscow, 
becomes lesser (Tamkin). Warsaw sees any "reset" between the White House and the Kremlin as potential risk in relations with the US, because they pose a danger of "rationalization of security" in the thinking of American elites. Such transactionism reduces the role of cultural factors (the community of democratic states) and historical past (United States always supported Poland: 14 Wilson points, postwars relief effort, alliance in the Second World War, 10 million Poles in the USA, support for Solidarity movement) in mutual relations and turns their automatism into a rational calculation of profits and losses. Noticeable improvements in RussoAmerican relations weaken the American resolve to regard Eastern Europe as crucial to American security.

The weakening role of axiological factors is very dangerous for smaller partner, because it introduces the threat of reducing the certainty of the allied reaction on the American side. That is why, possible rapprochement between Moscow and Washington has always been met with anxiety in Warsaw. The examples of politics which were observed with concern by Poland were: Clinton project "Partnership for Peace", Bush who noticed "soul in Putin's eyes" and then during Obama presidency when Hillary Clinton and Sergey Lavrov pressed the red reset button. Trump's campaign declarations about the desire to reexamine the US-Russian relations did not please Warsaw either.

Reducing automatism leads to rationalize relations, which contributes to the assessment of their quality from the perspective of costs and benefits. This is based on the transactionalism and bilateralism proclaimed by Donald Trump. Understanding partner relations in such manner favors to seek alliance's support on the basis of common interests. This approach is not unusual but in asymmetry between countries, it is difficult to balance the contribution of both partners to the alliance. This situation is not possible due to potential inequality and a different scale of involvement in mutual and global affairs. Both partners know it, so the declaration of "balance" as outcome on the part of the patron signifies willingness to downgrade of relations and sends a signal that the patron does not care about this relationship with weaker partner. Asymmetry should be understood as an objective fact and as a certain state of consciousness (Szklarski, 11). Therefore, both sides should develop such solutions that the consequences of this inequality could not make the patron feel used, and the perception of being useless did not appear on the side of the smaller partner.

In the asymmetric alliance, the value of a weaker country is naturally limited. Stronger side in this arrangement must take the responsibility for this imbalance expressed in material cost, provided services and trade imbalance. Shared axiological dimension makes it easier for a (willing) patron to justify to its citizens partners' disproportions in material contributions to the alliance. However, the cost of a weaker side in alliance is the loss of its freedom to decide about their politics and the perception of dependency on the international arena, meaning 
the inability to take a position contrary to the will of the patron. The Polish contribution to the asymmetric alliance with the US for example, included acceptance of the loss of sovereignty in favor of the patron, when it demanded contribution which potentially carried significant moral and legal penalty (secret CIA prison in Stare Kiejkuty). A side effect of being perceived by others as a state that always supports its patron is the label of an American "Trojan horse" in the European Union. Poland seemed to be willing to pay that symbolic price when during discussions in 2017 about EU needing to build up its military potential, Warsaw openly suggested that the military equipment procured for that purpose should come from the United States (Emmot).

\section{US view of the World}

In the United States, we are dealing with a "paradox of indifference" which is caused by American electorate. On the one hand, Americans attach little importance to foreign policy in the election act, even if the international situation should require it (Nincic, 139-140). On the other hand, Washington is perceived by US citizens as a "shining city on the hill", which is even obliged to spread and support the values of the American Creed all over the world (Manifest Destiny). Therefore, a smaller ally must define its interests and position in relation to the American, to give Washington room for maneuver, that is, to justify its policy in a country such as Poland in the light of values accepted by public opinion in the US. The foreign policy of the United States is governed by hard interests when there is a complicated situation in places little known to American public. However, in the rhetorical layer compliance with the Creedal values determines the acceptance of US foreign policy. Without this axiological legitimization, politics loses the status of a moral mission (Smith, 5).

The key role in directing US foreign policy, by constitutional design, is played by the president. His rights arise from the constitutional powers as the head of state reinforced by the US Supreme Court interpretations, the tradition established in everyday practice and the domination of the White House in public discourse (Fisher, 149-150). The language that American elite uses is simple and descriptions of the international situation is also accessible to an average voter (Burleigh). This can help a citizen to understand American arguments and actions. The consequence of this is often black and white and simplified image of the world and foreign policy necessary to control it. The perception of asymmetry and its impact on the positions and behaviors of partners in the alliance are an important element of the elite's thinking on both sides of the Atlantic. The next part of this study is devoted to these issues.

When we look at Polish attitudes towards America through the prism of actions and rhetoric of the political elites, experts, and major media then we can draw 
conclusions that the Polish raison d'etat since 1989 is the desire to please Washington and entangle it in the Polish interests. The effect of this tactic is to root Poland in the American minds as a stable and close ally deserving support. This tendency sometimes can even look caricatural. How else could be called lobbying in the European Union for the funds allocated for the development of modern military technologies to be spent on the purchase of American armaments as a part of building the European military structures (Wyborcza)? There is even a desperate desire to embroil Washington on the European continent as much as possible with the help of transfer of material resources (long term LNG deals, military equipment purchases, land grants for military installations). This policy fits in Trump's philosophy of transactional view of the world in which US engagement is incommensurate with the benefits they gain from the relationship. In the scientific literature, such an activity falls into the list of behaviors referred to as "bandwagoning" (Walt, 15) or "clientelism" (Sylvan, Majeski, 7).

The history of Polish-American relations is full of actions initiated by both parties, proving the actual cooperation and the will to perpetuate it. Examples of this type of policy, on the part of the US were: a stabilization fund for the Polish currency in the amount of 200 billion dollars, debt reduction by $70 \%$, reduction of the debt of the Paris Club (commercial banks) by 50\%, military cooperation, military education (Polish soldiers at American military colleges), regular CIA contacts with Polish intelligence, F16 rental to Polish air force before their purchase, support for Polish diplomatic efforts during the establishment of relations with united Germany, including support for confirmation of the border on the Odra and Nysa Łużycka rivers, investments in the Polish arms industry (helicopters), installation of elements of the missile defense system in Poland, rotational dislocation of American military units as a part of NATO - east flank reinforcement and recent permission to sell one of the most modern version of the Patriot missile system to Poland (Onet). On the level of everyday cooperation in the military field there are many projects on a smaller scale that consolidate the regularity of positive relations between Warsaw and Washington (The White House Office of the Press Secretary).

Poland has always supported the US on the international arena when they needed such backup at the UN or in the EU. What is more significant, Polish "investments" in the durability of relations with the US included burdensome and sometimes questionable actions such as: the participation in two interventions in Afghanistan and Iraq, post-war stabilization activities in both of these countries, providing access to the territory of Poland for anti-terrorist activities (the previously mentioned prison in Stare Kiejkuty), diplomatic support on international forums (EU-negotiations on proposed trade agreement - TTIP, UN-support for US recognition of Jerusalem as the capital of Israel) and acquisition of American weapons (F-16 fighter aircraft, Bell helicopters, Patriot missile system and possible 
purchase of HIMARS anti-aircraft missile system). Generally, Poland articulated skepticism when it was desired and demonstrated support when it was called on by the US. Warsaw extremely rarely criticized Washington's foreign policy. One of the most distinct example was an open letter written by 8 leaders of Central and Eastern Europe who reminded President Obama that Russia is conducting a revisionist policy aimed at recreating its sphere of influence in the region (Poprzeczny). However, when the government in Warsaw explicitly undermined the principles of liberal democracy and separation of powers, the United States started to condemn those changes in Poland. Doubt expressed by State Department spokesman and US ambassador was met in Warsaw with surprise and fear. The primary anxiety is the possible loss of the fundamental principle of Polish foreign policy, which for nearly 30 years has been looking for the closest ties with the US in order to entangle them into Polish security (Gazeta.pl).

The raison d'état in Polish-American relations has been to explore the opportunities/situations to publicly show mutual contribution to the alliance. The institutionalization of relations on many levels and in many policy dimensions supported by appropriate rhetoric emphasizing the mutual usefulness and durability of affairs contributes to this type of relationship (Kozłowski, 90-91). It seemed that both sides understood the foundation of their relations in this way and that it was inviolable.

At the same time, Washington and Warsaw have left themselves leeway to act on non-key issues. Poland wanted such freedom in contacts with its neighbors, especially Lithuania and Ukraine and above all in relations with the EU institutions. The Americans understood those actions and agreed on them until they did not affect their interests in the region. One of the example was the case with Polish support for the Ukrainian Revolution in 2014. According to Grzegorz Kozłowski, a longtime director of the Department of the Americas in the Polish Ministry of Foreign Affairs, it seemed that as part of the obvious structural asymmetry in Warsaw-Washington relations, the Americans accepted a declarative assumption of equality of partners with unequal potentials (Kozłowski, 85). The Americans tried to protect their relations with Poland and perhaps they behaved too restrained, not wanting to give the impression of being a new hegemon who replaced the Soviet Union.

Year 2017 and 2018 brought Washington's decisive and critical reaction to undermining the liberal constitutional principles. This is a proof that the time has come to communicate to the Polish partner the limits of freedom that the patron is willing to tolerate. From the reaction of the USA, it seems that Poland has exceeded the scope of "consent to disagreement" (Kupiecki, 64-65). In such situations, as in patronage relations, Washington without hesitation speaks about the internal policy of the client, considering it as a form of reminding of the character of entanglements resulting from structural asymmetry. The delimitation of the sphere of 
non-disruptive disagreement is never spelled out clearly. Good partners should be able to understand and respect their limitations almost intuitively.

According to Robert Kupiecki, a former Polish ambassador in the USA, "asymmetry is the reconciliation of dependencies" where both parties, in fear of losing the room for maneuver, are working together for the sake of an agreement (Kupiecki, 63). Therefore, latest disagreement on the Washington-Warsaw line is the moment of "harmonizing the balance." Poland needs to choose the right tactic to overcome the risk of Washington being ready to lower the level of current relations or even change the partner. Good relationship contain mechanisms to remove misunderstandings and now there is a need to test them.

It is unfortunate that problems between Washington and Poland are happening in the last two years because current administration in the White House has new approach to foreign policy and is ready to revise commitments in line with isolationistic and nativistic philosophy. Furthermore, more signals came from the State Department, an institution that was considered to be the guardian of continuity and institution that was reducing tensions in American foreign policy in the face of the uncertainty of the White House's attitudes (Pfiffner). A question arises as to whether the degree of institutionalization and the diversity of forms of cooperation and communication routes between Warsaw and Washington will be a sufficient barrier to prevent the redefinition of mutual perceptions? This is a problem for both sides because in the asymmetric allied relationship, the rules developed by partners are a value in itself (Kupiecki, 64-65). They give these relations predictable character and protection against undesirable change. In the light of the above mentioned inclination to weaken the rules of alliance articulated by the White House, the reprimand delivered by the Department of State i.e. the institution which represents stability, moderation, and continuity in American foreign policy acquires added weight.

There would be nothing worse for Poland than agreeing to "settle" relations with the US on transactional terms according to material measures. The momentary advantage for the US to export LNG and sell missiles and helicopters to Poland would not be able to balance asymmetries in the long run. If Polish authorities allow for business-like transactionism to become a backbone of the Polish-American relations, then they will be exposed to uncertainty as soon as the balance of relations in Washington is calculated in a way that is unsatisfactory for them. In addition, Poland has little influence on how Washington measures "balance." According to the theory of allied relations, automatism limits the room for maneuver and strengthens the bond between allies, and selective choice weakens ties and trusts. Selectivity leads to transactional relations and to thinking about the "shareholder return" from investments in Poland.

The regularity and intensity of Polish-American relations in recent years has been the key to their quality. Problems are prevented and neutralized from being 
perpetuated by regularity. Routinisation of relationships, multiplicity of dialogue channels (political and expert) make it easier to solve problems. For Poland in transatlantic relations it is important to base them on a mix of ideals and interests shared by both sides of the alliance. This is due to the fact that American policy is based on values that legitimize its policy. Poland must maintain a sense of community of values with America, so that Washington would maintain strong ties with Warsaw for idealistic reasons especially with the Trump administration.

Andrzej Dybczyński draws attention to the temporal dimension in allied relations, where alliances are formed "towards the future" (Dybczyński, Sojusze międzynarodowe, 15). In addition, he quotes Sabrotsky, who gives staggering statistics that $75 \%$ of alliances are not fulfilled (Dybczyński, Zarządzanie sojuszem asymetrycznym. Relacje Polska - USA, 39). The vast majority of these "betrayals" are committed by a stronger partner. Therefore, for Poland, there are important recommendations that can be summarized as follows: firstly, a certain state of entanglement in US interests is a natural state and must be accepted as a necessary evil. Secondly, searching for alternative, unconventional solutions that would supposedly reduce asymmetry is a waste of time. Poland can neither reduce the conflict with the enemy, Russia, nor develop allied alternatives and it also has no effect on the range of interests that connect them with the US. The only thing it can do is to increase its military potential but this solution requires a long-term program and substantial resources that Poland simply does not have. Therefore, the only way for Poland is to constantly monitor American engagement and react immediately to any signs of change in its character. Currently, Polish policy towards the US may be difficult because Donald Trump does not seem to have long-term political strategies in the Central and Eastern European region and his policies are guided only by a narrowly understood interest, mostly economic, not by ideals.

On two occasions the Trump administration expressed more vocal endorsement of democratic values: once in Hungary in defense of freedom of academic research when it came to the defense of the Central European University funded by George Soros, and second time in Poland in defense of freedom of media when American owned TVN network was attacked by the conservative government. One might say, that both interventions were not axiological but economic in nature. Washington propped up American owned businesses against conservative nationalistic governments attempting to regulate their activities.

\section{Measures employed as management of uncertainty}

Uncertainty management can be difficult as it requires a wide range of multidirectional activities. In the final part of the text we discuss the range of tactics available for risk management in asymmetrical allied relations. It is extremely important 
to look at them through the prism of the historical and cultural context of the Polish-American relations outlined above. The typology was based on the analysis of behavior, decisions, policy papers, press releases, statements, and documents of the Ministry of Foreign Affairs and the Ministry of Defense as they were reported by the media.

The "Polish typology" may be used in comparative analyses as it comprises most often utilized risk management measures adopted by junior partners in asymmetrical relations with the USA. It consists of options available to smaller partners in asymmetrical allied relations, which they can use to minimize the risk resulting from the unpredictability of Washington's actions and declarations. The following list contains actions as well as verbal declarations that have been divided into two categories depending on the level of submission to the patron and the degree of creativity in the search for alternatives to passivity. It must be remembered that the usability of these activities is in any case dependent on the situation in which they are undertaken.

Table 1. Typology of ways to manage risk used by a weaker partner as part of asymmetric alliance relations with the US

RISK MANAGEMENT TACTICS IN ASYMMETRICAL ALLIANCES - THE CASE OF POLISH-AMERICAN RELATIONS

\begin{tabular}{|c|c|c|}
\hline \multicolumn{2}{|c|}{ A. subordination - loyalty } & \\
\hline 1 & waiting for an explanation from Washington & $\sqrt{ }$ \\
\hline 2 & making yourself useful in essential matters signaled by Washington & \\
\hline 3 & supporting the controversial actions of the Trump administration & $\sqrt{ }$ \\
\hline 4 & creating a common axiological space & $\sqrt{ }$ \\
\hline 5 & verbal support for US policy & $\sqrt{ }$ \\
\hline 6 & $\begin{array}{r}\text { avoiding taking a position on contentious issues from the US, when } \\
\text { this does not apply to your own priorities }\end{array}$ & \\
\hline 7 & denying the existence of contentious issues & $\sqrt{ }$ \\
\hline 8 & showing willingness to submit to the will of the US & $\sqrt{ }$ \\
\hline 9 & supporting slogans about "special relations" with the US & $\sqrt{ }$ \\
\hline 10 & $\begin{array}{c}\text { seeking to confirm US interest in Poland, and then overinterpreting } \\
\text { it as an expression of American involvement }\end{array}$ & $\sqrt{ }$ \\
\hline 11 & $\begin{array}{c}\text { interpreting the words of the White House so that they would serve } \\
\text { Polish interests - creating an illusion of support }\end{array}$ & \\
\hline 12 & an attempt to persuade Washington to recognize Polish interests & \\
\hline 13 & acceptance of the new level of risk in mutual relations & \\
\hline
\end{tabular}




\begin{tabular}{|c|c|c|}
\hline \multicolumn{2}{|r|}{$\begin{array}{l}\text { RISK MANAGEMENT TACTICS IN ASYMMETRICAL ALLIANCES } \\
\text { - THE CASE OF POLISH-AMERICAN RELATIONS }\end{array}$} & $\begin{array}{c}\text { Action } \\
\text { taken } \\
\text { by } \\
\text { Poland }\end{array}$ \\
\hline \multicolumn{3}{|c|}{ B. adaptation - creativity } \\
\hline 14 & continuation of existing activities without changes & $\sqrt{ }$ \\
\hline 15 & creating independent spheres from the USA & \\
\hline 16 & adapting your own interests to avoid conflict with American interests & \\
\hline 17 & $\begin{array}{l}\text { formulating several priority expectations in relation to the US, i.e. } \\
\text { simplifying the hierarchy of own interests }\end{array}$ & \\
\hline 18 & support for American allies & $\sqrt{ }$ \\
\hline 19 & $\begin{array}{l}\text { building your own security resources to compensate for sense of } \\
\text { uncertainty }\end{array}$ & $\sqrt{ }$ \\
\hline 20 & $\begin{array}{l}\text { building bridges (access) to actors in Washington other than the } \\
\text { White House (Congress, Department of State, Pentagon, lobbies, ...) }\end{array}$ & $\sqrt{ }$ \\
\hline 21 & participation in international cooperation initiatives & $\sqrt{ }$ \\
\hline 22 & searching for alternative bilateral relations & \\
\hline 23 & search for support from American allies & \\
\hline 24 & starting a dispute with Washington & \\
\hline 25 & abandoning Washington & \\
\hline
\end{tabular}

Source: typology based on Author's own analyses

The methods of risk management in the asymmetric alliance include two types of actions: subordination or adjustment. Actions from both categories are undertaken with the intention not to disturb the perception that security continues to be provided by the patron at previous level. Activities in the category of "subordination" is primarily a response to what Washington is doing. Therefore weaker countries like Poland are willing to accept American leadership. They have to comprehend the American view of the world and their own political actions must be in line with expectations of Washington. Activities in the "adaptation" category are more creative and express the desire to redefine their own priorities, agreeing on common fields of action and thinking, as well as indicate the search for opportunities to influence Washington policy through other actors on the domestic and international scene. There is also the option of confronting or replacing the patron or even abandoning it. All these possibilities have to compensate for the threat of US policy which undermine the stability of allied relations. 


\section{Conclusions or lessons learned(?)}

The above table shows that the Polish authorities have taken a number of actions from both categories, with the majority of activities from the "subordination" category. However, there is a lack of sufficient discussion among Polish political elites about the raison d'etat and priorities in international politics. What is more, there is no sufficient planning and coordination in the implementation of foreign policy. One example was the "Polish-American economic summit" which took place at the beginning of 2018 in Florida, which should become one of the most important topics in the Polish media and in bilateral relations, but this did not happen. It was because of the fact that at the same time the Polish parliament passed a controversial law (previously mentioned IPN law) that banned any criticism of Polish society's behavior towards the Jews during the Holocaust (Wrona). It invoked concerns about freedom of speech, scientific research and caused widespread criticism in Israel and in the United States. Instead of dealing with economic relations and possibility of new fields of cooperation, the media were dominated by discussions about the past. All the expected benefits from the economic summit were overshadowed by the conflict over interpretations of history and civil rights. The good relations with Israel were weakened, which is the key ally of the USA. The American Jewish lobby was also antagonized and there was an immediate strong reaction in Washington. This verbal disapproval contained something that for the smaller ally in the asymmetrical relationship has to awake the greatest anxiety - publicly questioning the validity of the alliance.

The events from the turn of January and February 2018 could have been mitigated if there were more stable authorities in Washington and Warsaw. The new philosophy of Donald Trump America First carries the threat of isolationism and nativism. In addition, bilateralism and transactionalism characterize the weakening of the importance of ideological and valuable dimensions of foreign policy. There is a real possibility that in a situation of tensions, the US will take the opportunity to bring relations with Warsaw to a lower rank.

Recent amendments to the Holocaust law in June 2018 which resulted in the improvement of relations with Israel, together with the signing of a deal to purchase Patriot missiles seem to have terminated the dry spell in Poland's relations with the US. Evidence of this came in the form of an official visit of President of Poland, Andrzej Duda in Washington in September 2018. Yet it is far too early to say that the axiological bond and automatism have returned.

Politics of Poland and other American allied countries in the Central and Eastern Europe region show that the increase in uncertainty about the stability and level of the cooperation with the US causes them to comply with all real or imagined US expectations. The proof for that in case of Poland, is the choice of tactic that minimize the risk of weakening the security provided by the United States. 


\section{Works Cited}

Beaumont, P. Trump threatens to cut aid to countries over UN Jerusalem Vote. "The Guardian" (December 2017). Web. 12 January 2018, https://www.theguardian. com/us-news/2017/dec/20/donald-trump-threat-cut-aid-un -jerusalem-vote

Bieńczyk-Missala, A. Poland's foreign and security policy: main directions, "Revista UNISCI / UNISCI Journal”, no. 40 (Enero / January 2016), pp. 101-117.

Burleigh, N. Trump speaks at fourth-grade level, lowest of last 15 US presidents. "Newsweek". Web. 1 August, 2018, https://www.newsweek.com/trump-fire-and -fury-smart-genius-obama-774169

Departament Stanu USA znów mówi o ustawie o IPN 'Obawiamy się o relacje Polski z innymi krajami'. Gazeta.pl. (2.02.2018). Web. 8 February 2018, http:// wiadomosci.gazeta.pl/wiadomosci/7,114884,22972416,departament-stanu-usaznow-mowi-o-ustawie-o-ipn-obawiamy-sie.html.

Dybczyński, A. Sojusze międzynarodowe. Warsaw: Scholar, 2014.

Dybczyński, A. Zarzadzanie sojuszem asymetrycznym. Relacje Polska - USA, [in:] Niekonfrontacyjna asymetria $w$ relacjach polsko-amerykańskich, ed. B. Szklarski. Warszawa: Ministerstwo Spraw Zagranicznych, 2015.

Emmot, R. EU countries agree to create a European mega-army, "Business Insider" (November 13, 2017). Web. 15 July 2018, www.businessinsider.com/eu-countries -agree-mega-army-2017-11?IR=T.

Fact Sheet: US-Poland Relations. The White House Office of the Press Secretary. (July 2016). Web. 10 June 2018, https://obamawhitehouse.archives.gov/the-pressoffice/2016/07/08/fact-sheet-us -poland-relations.

Fisher, L. Foreign Policy Powers of the President and Congress, "The Annals of the American Academy of Political and Social Science”, vol. 499 (Sep., 1988), pp. 148-159.

Kiwerska, J. Kwestie bezpieczeństwa w stosunkach polsko-amerykańskich. Trendy i perspektywy, [in:] Bezpieczeństwo Polski. Współczesne wyzwania, ed. S.W. Potyrała. Warszawa: Difin, 2014.

Kozłowski, G. Asymetria relacji polsko-amerykańskich a stan perspektywy ich rozwoju (możliwość ograniczenia nierównowagi), [in:] Niekonfrontacyjna asymetria w relacjach polsko-amerykańskich, ed. B. Szklarski. Warszawa: Ministerstwo Spraw Zagranicznych, 2015.

Kupiecki, R. W cieniu asymetrii. Polsko-amerykańskie stosunki $w$ dziedzinie bezpieczeństwa, [in:] Niekonfrontacyjna asymetria $w$ relacjach polsko-amerykańskich, ed. B. Szklarski. Warszawa: Ministerstwo Spraw Zagranicznych, 2015.

Kuźniar, R. Poland's Foreign Policy after 1989. Warsaw: Scholar, 2009.

Łaciński, P. Przejawy przyjaznej asymetrii w relacjach USA - Ameryka Łacińska. Casus Meksyku, [in:] Niekonfrontacyjna asymetria w relacjach polsko-amerykańskich, ed. B.Szklarski. Warszawa: Ministerstwo Spraw Zagranicznych, 2015. 
Nincic, M. External Affairs and the Electoral Connection, [in:] The Domestic Sources of American Foreign policy: Insights and Evidence, ed. J. McCormick. Lanham: Rowman \& Littlefield Publishers, 2012.

Pfiffner, J. Cabinet secretaries versus the White House Staff. The Brookings Institution Edu. (2015). Web 13 August 2018, https://www.brookings.edu/blog/ fixgov/2015/03/24/cabinet-secretaries-versus-the-white-house-staff/.

Polska kupi system Patriot. Wiemy ile będzie kosztować i kiedy zostanie podpisana umowa. „Onet Wiadomości” (7 February 2018). Web. 13 June 2018, https:// wiadomosci.onet.pl/kraj/polska-kupi-system-patriot-wiemy-ile-bedzie-kosztowac -i-kiedy-zostanie-podpisana/blxbdzn.

Polska ustawa o IPN powoduje eskalację krytyki Waszyngtonu. „Gazeta Wyborcza” (16 February 2018), p. 2. (editorial). Web. 18.August 2018.

Poprzeczny, J. Obama said: don't abandon Central and Eastern Europe. "NewsWeekly" (September 2009). Web. 10 February 2018, http://newsweekly.com.au/article. php?id=3721.

Smith, T. America's Mission: The United States and the Worldwide Struggle for Democracy. Princeton: Princeton University Press, 2012.

Stone, J. Support for EU membership reaches record high in Poland despite showdown with Brussels. "The Independent" (January 2018). Web. 13 January 2018, http:// www.independent.co.uk/news/world/europe/poland-eu-membership-supportfor-membership-courts-rule-of-law-mateusz-morawiecki-juncker-a8149876.html.

Sylvan, D. and Majeski, S. US Foreign Policy in Perspective: Clients, enemies and empire. New York: Routledge, 2009.

Szklarski, B. Niekonfrontacyjna asymetria - konceptualizacja pojęcia, [in:] Niekonfrontacyjna asymetria $w$ relacjach polsko-amerykańskich, ed. B. Szklarski. Warszawa: Ministerstwo Spraw Zagranicznych, 2015.

Szymański, M. Security Franchising: Polish American Defense Cooperation, [in:] Poland in Transatlantic Relations after 1989: Miracle Fair, ed. M. Zachara. Newcastle: Cambridge Scholars, 2017.

Świerczyński, M. Polska ustawa o IPN powoduje eskalację krytyki Waszyngtonu. „Polityka Insight” (7 February 2018). Web. 18 December 2018, https://www. polityka.pl/tygodnikpolityka/swiat/1737260,1,polska-ustawa-o-ipn-powodujeeskalacje-krytyki-waszyngtonu.read.

Tamkin, E. With EU and U.S. Distracted, Central and Eastern European Countries Crack Down on Civil Society. "Foreign Policy" (March 2017). Web. 23 December 2017, http://foreignpolicy.com/2017/03/09/with-eu-and-us-distracted-central-andeastern-european-countries-crack-down-on-civil-society/.

Walt, S. The Origins of Alliance. Ithaca: Cornell University Press, 1990. 
Wrona, M. Polsko-Amerykański Szczyt Przywództwa na Florydzie. W tle spór o ustawę o IPN. Fakty TVN24. (11 February 2018). Web. 25 August 2018, https:// fakty.tvn24.pl/ogladaj-online,60/polsko-amerykanski-szczyt-przywodztwa-naflorydzie,814227.html.

Zachara, M. Poland in Transatlantic Relations after 1989: Miracle Fair. Newcastle: Cambridge Scholars. 2017.

Zając, J. Asymetria $w$ stosunkach polsko-amerykańskich $w$ zmieniającym się ładzie międzynarodowym, [in:] Niekonfrontacyjna asymetria $w$ relacjach polsko-amerykańskich, ed. B. Szklarski. Warszawa: Ministerstwo Spraw Zagranicznych, 2015.

Zięba, R. Polityka zagraniczna Polski w strefie euroatlantyckiej. Warszawa: Wydawnictwo Uniwersytetu Warszawskiego, 2013.

Bohdan Szklarski - an Associate Professor of Political Science, Graduate of the English Institute, Warsaw University and the Department of Political Science, Northeastern University, Boston. In his almost 30 years of teaching he has taught at numerous American and Polish Universities. He served as a director of the American Studies Center, Warsaw University in years 2012-2016. Now he is a head of the Center for the Study of Leadership there. He also lectures at the Collegium Civitas a college of social sciences where for over 10 years he served as a Chair of the Department of Political Science. Prof. Szklarski's research interests include: American Presidency, political leadership, American political culture and institutions, comparative politics, political communication and political anthropology. He frequently appears as a commentator on American and Polish political events in the media. Privately a happy family man and a golden retriever and NFL fan.

Piotr Ilowski - PhD student at the Institute of Political Studies at Polish Academy of Science (PAN), graduated from International Relations at Collegium Civitas. He is now studying American Studies at the University of Warsaw. He completed internship at the Center for Eastern Studies (OSW Poland). He wrote in Nowastrategia.pl, Centrum Schumpetera and in Bliskiwschod.pl. He was interested with the problems of the Middle East, the situation of Turkey and the relationship of the United States in this region. Currently, he deals with the problems of populism, their historical sources as well as the political, social and foreign policy of the United States. 